\title{
EFEKTIVITAS MODEL PEMBELAJARANTEAM ASSISTED INDIVIDUALIZATION (TAI) DAN GROUP INVESTIGATION (GI) TERHADAP PRESTASI BELAJAR MATEMATIKA DITINJAU DARI MOTIVASI BELAJAR SISWA
}

\section{Effectiveness of Team Assisted Individualization (TAI) and Group Investigation (GI) Learning Models on Mathematical Learning Achievement Viewed from Student Learning Motivation}

\author{
Erny Untari ${ }^{1 *}$, Ana Wahyuningrum ${ }^{2}$ \\ ${ }^{1,2}$ Jurusan Pendidikan Matematika,STKIP PGRI Ngawi \\ Jln. Raya Klitik Km. 05Kab. Ngawi, Provinsi Jawa Timur, Indonesia \\ e-mail:1*erny1703@gmail.com;2anawto@gmail.com; \\ Corresponding author*
}

\begin{abstract}
Abstrak
Penelitian ini bertujuan untuk mengetahui perbedaan prestasi belajar dari masing-masing model pembelajaran, motivasi serta interaksinya. Penelitian ini menggunakan metode eksperimen dengan populasi seluruh siswa kelas VIII SMP Negeri 2 Kwadungan yang diambil 2 kelas sebagai kelas eksperimen I dan kelas eksperimen II. Sampel penelitian diambil dengan teknik(purposive sampling). Teknik pengumpulan data menggunakan metode angket dan metode tes soal kognitif. Uji hipotesis penelitian menggunakan anava dua jalan dengan sel tak sama. Uji lanjut pasca anava menggunakan uji Scheffe. Kesimpulan dari hasil penelitian ini adalah (1) Prestasi belajar matematika siswa dengan model Team Assisted Individualization lebih baik dibandingkan prestasi belajar matematika siswa dengan model Group Investigation, (2) Siswa dengan motivasi tinggi mempunyai prestasi belajar matematika yang relatif sama dengan siswa motivasi sedang, siswa dengan motivasi tinggi dan sedang mempunyai prestasi belajar matematika yang lebih baik dibandingkan siswa dengan motivasi rendah, (3) Tidak terdapat interaksi antara model pembelajaran dan motivasi terhadap prestasi belajar matematika siswa.
\end{abstract}

Kata Kunci : Efektivitas, Group Investigtion, motivasi, prestasi belajar, Team Assisted Individualization.

\begin{abstract}
This study aims to determine the differences in learning achievement of each learning model, motivation and interaction. This study uses an experimental method with a population of all eighth grade students of State Middle School 2 Kwadungan taken 2 classes as experimental class I and experimental class II. The research sample was taken by technique (purposive sampling). Data collection techniques used the questionnaire method and cognitive question test methods. The research hypothesis test uses two-way anova with unequal cells. Post-anova follow-up tests using the Scheffe test. The conclusions from the results of this study are (1) Mathematics learning achievement of students with the Team Assisted Individualization model is better than students' mathematics learning achievement with the Group Investigation model, (2) High motivated students have relatively similar mathematics learning achievement with moderate motivation students, students with high and moderate motivation have better mathematics learning achievement than students with low motivation, (3) There is no interaction between learning models and motivation towards students' mathematics learning achievement.
\end{abstract}

Keywords: Effectiveness, Group Investigation, learning achievement, motivation, Team Assisted Individualization 


\section{PENDAHULUAN}

Pendidikan merupakan salah satu faktor penentu kualitas suatu bangsa. Dalam hal ini pemerintah dan sekolah memiliki peran penting karena pemerintah sebagai pihak yang membuat kebijakan bidang pendidikan. Sedangkan sekolah sebagai tempat untuk menjalankan kebijakan yang terkait dengan penyelenggara pendidikan. Pendidikan di sekolah berkaitan dengan pembelajaran yang dilakukan oleh guru dan peserta didik di tingkat kelas. Keberhasilan suatu pembelajaran dapat dilihat dari segi proses pendidikan serta hasil pendidikan. Ditinjau dari proses, dikatakan berhasil apabila sebagian besar peserta didik terlibat secara aktif, baik secara fisik, mental maupun sosial dalam proses pembelajaran. Ditinjau dari hasil, apabila terjadi perubahan perilaku positif pada diri peserta didik yang meliputi ranah kognitif, afektif dan psikomontorik [1]. Dengan demikian perlu adanya perubahan sistem pembelajaran yang tidak lagi berpusat pada guru melainkan kepada peserta didik, sehingga guru memiliki peran sebagai fasilitator yang membimbing dan mengkoordinasi kegiatan belajar. Hal ini sangat efektif terutama pada pembelajaran matematika. Matematika adalah ilmu pengetahuan yang mendasari berbagai ilmu pengetahuan lain, karena itu matematika sangat perlu diajarkan pada semua jenjang pendidikan. Banyak peserta didik yang menganggap matematika sebagai pelajaran yang relatif sulit sehingga membentuk kesan dan pengalaman secara negatif yang berdampak buruk bagi motivasi belajar matematika [2].

Prestasi belajar matematika tergolong masih rendah. Ada beberapa faktor yang mempengaruhi rendahnya prestasi belajar peserta didik. Diantaranya faktor eksternal dan faktor internal. Adapun faktor eksternal adalah faktor yang berasal dari luar peserta didik. Model pembelajaran merupakan faktor eksternal yang harus diperhatikan. Pemilihan model pembelajaran yang kurang sesuai dengan karakteristik peserta didik menjadi penyebab rendahnya prestasi. Pada kenyataannya masih banyak guru matematika yang menggunakan model pembelajaran langsung dalam penyampaian materi pembelajaran. "Traditional classroom communication is characterised by "teacher dominated classroom talk, most learnes silent for most of the time" [3]. Hal tersebut menjelaskan bahwa dalam pembelajaran tradisional guru lebih dominan, sedangkan peserta didik hanya diam mendengarkan penjelasan guru dalam waktu yang lama. Hal ini mengakibatkan peserta didik akan cepat bosan dan kurang aktif dalam proses belajar mengajar dan menyebabkan pencapaian pembelajaran kurang maksimal. Sehingga, diperlukan pembelajaran yang mengacu pada peserta didik. Salah satunya adalah model pembelajaran kooperatif dimana peserta didik bekerja dalam kelompok kecil yang saling membantu antara peserta didik lainnya sehingga peserta didik termotivasi untuk melaksanakan kegiatan belajar dengan aktif dan tidak mudah bosan.

Model pembelajaran Team Assisted Individualization (TAI) dan Group Investigation (GI) merupakan model pembelajaran kooperatif yang dapat dipilih untuk mengoptimalkan prestasi belajar peserta didik. Model pembelajaran TAI terdiri dari kelompok kecil yang heterogen dengan latar belakang dan cara berfikir yang berbeda untuk saling membantu terhadap peserta didik lain yang membutuhkan bantuan[4]. Sehingga peserta didik termotivasi untuk belajar sehingga diharapkan dapat meningkatkan prestasi belajar. Group Investigation (GI) adalah model pembelajaran kooperatif yang memiliki penekanan pada partisipasi dan aktivitas peserta didik untuk mencari secara mandiri materi pelajaran yang akan dipelajari [5]. Dalam proses belajar, peserta didik belajar dari pengalaman sendiri, mengkonstruksi pengetahuan kemudian memberi makna pada pengetahuan itu. Melalui proses belajar yang mengalami sendiri, menemukan sendiri dan secara berkelompok, maka peserta didik menjadi senang, sehingga tumbuh motivasi peserta didik.

Faktor lain yang mempengaruhi prestasi belajar siswa adalah motivasi. Motivasi belajar yaitu keinginan atau dorongan untuk belajar [6]. Agar siswa terdorong oleh kemauannya sendiri untuk mengatasi berbagai kesulitan belajar yang dihadapi perlu adanya motivasi yang besar. Dengan menggunakan metode Team Assisted Individualization (TAI) dan Group Investigation (GI) diharapkan motivasi siswa dapat meningkat untuk belajar sehingga meningkatkan prestasi belajar. Kurangnya motivasi belajar peserta didik peserta didik merupakan salah satu penyebab rendahnya prestasi belajar yang berasal dari peserta didik itu sendiri. [7] "Motivations raises question on why people behave in the way they do it. An individual chould therefore, from psychologists' point of view, be seen as politically, socially and academically motivated depending on the motive behind his or her activities". Hal ini menjelaskan bahwa motivasi menimbulkan pertanyaan mengapa orang bertingkah laku dengan cara yang mereka lakukan. Secara individu, dari sudut pandang psikologis, motivasi tergantung pada dorongan atas kegiatan atau aktivitas yang mereka lakukan. Dapat diartikan, motivasi adalah dorongan yang mendasari setiap kegiatan yang dilakukan. Adanya motivasi yang besar dalam diri siswa merupakan syarat agar siswa terdorong oleh kemauannya sendiri untuk mengatasi berbagai kesulitan belajar yang dihadapi. 
Tujuan penelitian ini untuk mengetahui perbedaan prestasi belajar dari masing-masing model pembelajaran TAI dan GI, kategori motivasi belajar siswa yang memberikan prestasi belajar matematika siswa lebih baik, kategori motivasi tinggi, sedang atau rendah dan adanya interaksi antara model pembelajaran dengan motivasi siswa terhadap prestasi belajar siswa.

\section{METODE PENELITIAN}

Penelitian ini dilakukan di SMP Negeri 2 Kwadungan kelas VIII tahun ajaran 2018/2019. Penelitian ini termasuk penelitian kuantitatif. Sesuai dengan tujuan penelitian, maka dalam penelitian ini menggunakan metode eksperimen yang menggunakan desain anava 2 jalan sel tak sama. Faktor pertama (A) adalah model pembelajaran TAI. Faktor kedua (B) adalah model pembelajaran GI.

Teknik pengumpulan data yang digunakan dalam penelitian kuantitatif ini adalah metode angket dan metode tes [8]. Metode angket digunakan untuk mengukur motivasi siswa terhadap pelajaran matematika. Sedangkan metode tes digunakan untuk mengukur prestasi belajar matematika siswa. Tes yang digunakan adalah tes objektif dengan bentuk soal pilihan ganda yang terdiri dari 20 soal yang dikerjakan dalam waktu 45 menit. Penilaian tes dilakukan untuk menilai prestasi belajar perorangan.

Teknik analisis data yang digunakan dalam penelitian ini meliputi uji pendahuluan yaitu uji keseimbangan, uji prasyarat yang meliputi uji normalitas dan uji homogenitas, dan uji hipotesis menggunakan uji analisis varian dengan sel tak sama dan uji pasca anava [9].

\section{HASIL DAN PEMBAHASAN}

\subsection{Hasil Penelitian}

Data penelitian terdiri dari kemampuan awal siswa sebelum dan sesudah diberi perlakuan, prestasi belajar dan data motivasi siswa yang terdiri atas motivasi tinggi, sedang dan rendah. Pengambilan sampel dengan cara Purposive sampling yaitu pengambilan sampel menggunakan pertimbangan tertentu, dari pengambilan sampel tersebut, didapat kelas VIII A sebagai kelas eksperimen I dengan menggunakan model pembelajaran Team Assisted Individualization dan kelas VIII C sebagai kelas eksperimen II dengan menggunakan model pembelajaran Group Investigation.

\section{Data Prestasi Belajar Siswa}

Data ini digunakan untuk mengetahui kemampuan awal kelas eksperimen. Data prestasi belajar siswa sebelum dan sesudah diberi perlakuan menggunakan model pembelajaran Team Assisted Individualization dan Group Investigation dapat dilihat pada Tabel 1, sebagai berikut:

Tabel 1. Data Prestasi Belajar siswa sebelum dan sesudah diberi perlakuan

\begin{tabular}{lccc}
\hline \multicolumn{1}{c}{$\begin{array}{c}\text { Kelas } \\
\text { Eksperimen }\end{array}$} & Jumlah & Siswa & \multicolumn{2}{c}{ Rata - Rata Nilai Ulangan } \\
\cline { 3 - 4 } $\begin{array}{l}\text { (I) Team Assisted } \\
\text { Individualization }\end{array}$ & 32 & Sebelum diberi perlakuan & Sesudah diberi perlakuan \\
\hline $\begin{array}{l}\text { (II) Group } \\
\text { Investigation }\end{array}$ & 30 & 58,43 & 75,46 \\
\hline
\end{tabular}

\section{Data Motivasi Belajar Siswa}

Data ini digunakan untuk mengetahui prestasi belajar siswa berdasarkan kategori motivasi tinggi, sedang dan rendah. Rangkuman data motivasi belajar siswa dapat dilihat pada Tabel 2, sebagai berikut :

Tabel 2. Data Prestasi Belajar siswa sebelum dan sesudah dilakukan penelitian

\begin{tabular}{cccc}
\hline Kelas Eksperimen & $\begin{array}{c}\text { Kategori } \\
\text { Motivasi }\end{array}$ & $\begin{array}{c}\text { Jumlah } \\
\text { Siswa }\end{array}$ & $\begin{array}{c}\text { Rata - Rata Nilai } \\
\text { Ulangan }\end{array}$ \\
\hline (I) Team Assisted Individualization & Tinggi & 9 & 87,78 \\
\hline & Sedang & 17 & 76,3 \\
\hline & Rendah & 6 & 49,16 \\
\hline (II) Group Investigation & Tinggi & 7 & 77,85 \\
\hline & Sedang & 16 & 70,62 \\
\hline & Rendah & 7 & 45,71 \\
\hline
\end{tabular}


Berdasarkan data tersebut menunjukkan bahwa siswa dengan motivasi tinggi mempunyai prestasi belajar yang lebih baik dibandingkan siswa yang mempunyai motivasi sedang dan rendah. Sedangkan siswa yang mempunyai motivasi sedang mempunyai prestasi belajar yang lebih baik dibandingkan siswa yang mempunyai motivasi rendah.

\subsection{Hasil Pengujian Hipotesis}

\section{A. Analisis Uji Pendahuluan}

\section{Uji Keseimbangan}

Uji keseimbangan dilakukan untuk mengetahui apakah kelompok eksperimen I dan kelompok eksperimen II mempunyai kemampuan yang sama. Hasil analisis data dengan menggunakan uji t pada tingkat signifikan $\alpha=0,05$ menunjukkan bahwa $\mathrm{t}_{\text {hit }}=0,0193$. Daerah kritik untuk uji ini $\mathrm{DK}=\{\mathrm{t} \mid \mathrm{t}>$ 2,000\}. Ini berarti $\mathrm{H}_{0}$ diterima, sehingga disimpulkan bahwa kedua kelompok mempunyai kemampuan yang sama.

\section{Uji Normalitas}

Uji normalitas digunakan untuk mengetahui apakah data sampel berasal dari populasi yang berdistribusi normal. Uji normalitas pada penelitian ini menggunakan metode Lilliefors dengan tingkat signifikan $\alpha=$ 0,05. Hasil analisis uji normalitas kelompok eksperimen I menunjukkan bahwa $L=0,0952$. Daerah kritik untuk uji ini $\mathrm{DK}=\left\{\mathrm{L} / \mathrm{L}>\mathrm{L}_{0,05 ; 32}=0,1566\right\}$. Ini berarti data kelompok eksperimen I berasal dari populasi yang berdistribusi normal. Sedangkan kelompok eksperimen II menunjukkan bahwa $L=0,1420$. Daerah kritik untuk uji ini $\mathrm{DK}=\left\{\mathrm{L} / \mathrm{L}>\mathrm{L}_{0,05 ; 30}=0,161\right\}$. Sehingga data kelompok eksperimen II berasal dari populasi yang berdistribusi normal.

\section{Uji Homogenitas}

Uji homogenitas digunakan untuk mengetahui apakah variansi - variansi dari sejumlah populasi sama atau tidak. Hasil analisis uji homogenitas pada tingkat signifikan $\alpha=0,05$ menunjukkan bahwa $\chi_{\text {obs }}^{2}=$ 0,0525. Daerah kritik untuk uji ini $\mathrm{DK}=\left\{\mathrm{x}^{2} / \mathrm{x}^{2}>\mathrm{x}_{0,05 ; 1}^{2}=3,841\right\}$. Ini berarti $\mathrm{H}_{0}$ diterima, sehingga dapat disimpulkan bahwa data sampel kedua kelompok homogen.

\section{B. Analisis Uji Hipotesis}

Uji Normalitas

Rangkuman hasil uji normalitas dapat dilihat pada Tabel 3, sebagai berikut:

Tabel 3. Uji Normalitas

\begin{tabular}{|cccccc|}
\hline Kelompok Kelas & Kategori & $\begin{array}{c}\text { Jumlah } \\
\text { Sampel }\end{array}$ & $\mathbf{L}_{\text {obs }}$ & $\mathbf{L}_{\text {tabel }}$ & Keputusan Uji \\
\hline $\begin{array}{c}\text { Team Assisted } \\
\text { Individualization }\end{array}$ & Motivasi Tinggi & 9 & 0,1861 & 0,271 & Berdistribusi Normal \\
\hline & Motivasi Sedang & 17 & 0,1801 & 0,206 & Berdistribusi Normal \\
\hline & Motivasi Rendah & 6 & 0,2774 & 0,319 & Berdistribusi Normal \\
\hline Group Investigation & Motivasi Tinggi & 7 & 0,1617 & 0,3 & Berdistribusi Normal \\
\hline & Motivasi Sedang & 16 & 0,1056 & 0,22 & Berdistribusi Normal \\
\hline & Motivasi Rendah & 7 & 0,2355 & 0,3 & Berdistribusi Normal \\
\hline
\end{tabular}

Dari rangkuman analisis uji normalitas menunjukan bahwa data kelompok eksperimen I, kelompok eksperimen II maupun kelompok kategori motivasi tinggi, motivasi sedang dan motivasi rendah berasal dari populasi yang berdistribusi normal.

\section{Uji Homogenitas}

Rangkuman hasil penelitian uji homogenitas dapat dilihat pada Tabel 4, sebagai berikut: 
Tabel 4. Uji Homogenitas

\begin{tabular}{|ccccc|}
\hline Uji Homogenitas & $x^{2}{ }_{\text {obs }}$ & DK & Keputusan Uji & Kesimpulan \\
\hline $\begin{array}{c}\text { Kelas eksperimen Team Assisted } \\
\text { Individualization dan Group Investigation }\end{array}$ & $-1,6429$ & 3,8414 & $\mathrm{H}_{0}$ Diterima & Homogen \\
\hline
\end{tabular}

Berdasarkan hasil rangkuman analisis uji homogenitas tersebut menunjukkan menunjukkan bahwa $\chi_{\text {obs }}^{2}$ $=-1,6429$. Daerah kritik untuk uji ini $\mathrm{DK}=\left\{\mathrm{x}^{2} / \mathrm{x}^{2}>\mathrm{x}_{0,05 ; 1}^{2}=3,8414\right\}$. Ini berarti $\mathrm{H}_{0}$ diterima, sehingga kelompok eksperimen I dan kelas eksperimen II adalah homogen.

\section{Keputusan Uji Hipotesis}

berdasarkan analisis uji prasyarat menunjukkan bahwa sampel data amatan berasal dari populasi yang berdistribusi normal dan masing-masing kategori variabel data homogen. Dengan demikian, analisis variansi dapat dilanjutkan. Rangkuman hasil uji hipotesis pada analisis varian 2 × 3 pada tingkat signifikan $\alpha=0,05$ dapat dilihat pada Tabel 5, sebagai berikut:

Tabel 5. Uji Hipotesis

\begin{tabular}{|lrrrrrl|}
\hline \multicolumn{1}{|c}{ Sumber } & \multicolumn{1}{c}{ JK } & dk & \multicolumn{1}{c}{ RK } & \multicolumn{1}{c|}{ F $_{\text {obs }}$} & \multicolumn{1}{c|}{ F $_{\text {tabel }}$} & $\begin{array}{c}\text { Keputusan } \\
\text { Uji }\end{array}$ \\
\hline Model Pembelajaran (A) & 642,9458 & 1 & 642,9458 & 4,2202 & 4,0130 & $\mathrm{H}_{0}$ ditolak \\
\hline Motivasi (B) & 11975,8977 & 2 & 5987,9488 & 39,3044 & 3,1619 & $\mathrm{H}_{0}$ ditolak \\
\hline Interaksi (AB) & 94,1337 & 2 & 47,0669 & 0,3089 & 3,1619 & $\mathrm{H}_{0}$ diterima \\
\hline Galat & 8531,4834 & 56 & 152,3479 & & & \\
\hline Total & 21244,4606 & 61 & & & & \\
\hline
\end{tabular}

a) $\mathrm{F}_{\mathrm{a}}: \mathrm{F}_{0,05 ; 1 ; 56}=4,0130 ; \mathrm{DK}=\left\{\mathrm{F} / \mathrm{F}_{\mathrm{a}}>4,0130\right\} ; \mathrm{F}_{\mathrm{obs}}=4,2202$.

$\mathrm{H}_{0 \mathrm{~A}}$ ditolak, ini berarti terdapat perbedaan antara model pembelajaran Team Assisted Individualization dan Group Investigation terhadap prestasi belajar matematika siswa. Diketahui bahwa rata-rata hasil tes belajar matematika model pembelajaran kooperatif tipe $T A I$ adalah 75,4688 dan model pembelajran GI adalah 66,5. Sehingga dapat disimpulkan bahwa pembelajaran Team Assisted Individualization lebih baik dibandingkan model pembelajaran Group Investigation. Hal ini sesuai bahwa adanya pengembangan kemampuan peserta didik pada model pembelajaran TAI, sehingga siswa mempunyai kesempatan yang sama untuk menyampaikan ide pada saat belajar kelompok[10] dan didukung dengan penghargaan bagi kelompok yang berprestasi sehingga memacu siswa untuk belajar lebih giat [11]

b) $\mathrm{F}_{\mathrm{b}}: \mathrm{F}_{0,05 ; 2 ; 56}=3,1619 ; \mathrm{DK}=\left\{\mathrm{F} / \mathrm{F}_{\mathrm{b}}>3,1619\right\} ; \mathrm{F}_{\mathrm{obs}}=39,3044$.

$\mathrm{H}_{0 \mathrm{~B}}$ ditolak, ini berarti terdapat perbedaan antara motivasi tinggi, sedang dan rendah terhadap prestasi belajar matematika siswa.

c) $\mathrm{F}_{\mathrm{ab}}: \mathrm{F}_{0,05 ; 2 ; 56}=3,1619 ; \mathrm{DK}=\left\{\mathrm{F} / \mathrm{F}_{\mathrm{ab}}<3,1619\right\} ; \mathrm{F}_{\mathrm{obs}}=0,3089$.

$\mathrm{H}_{0 \mathrm{AB}}$ diterima, ini berarti tidak ada interaksi antara model model pembelajaran Team Assisted Individualization dan Group Investigation terhadap prestasi belajar matematika siswa ditinjau dari motivasi. Hal ini dimungkinkan karena tidak adanya variabel bebas lain yang tidak digunakan dalam penelitian ini yang juga berpengaruh diantaranya minat siswa, IQ, gaya belajar siswa dan lain-lain[12].

\section{Analisis Uji Lanjut}

Hasil uji anava dua jalan dengan sel tak sama didapat $\mathrm{H}_{0 \mathrm{~A}}$ dan $\mathrm{H}_{0 \mathrm{~B}}$ ditolak, maka dapat disimpulkan untuk $\mathrm{H}_{0 \mathrm{~A}}$ ditolak bahwa ada perbedaan yang signifikan antara model pembelajaran Team Assisted Individualization dan model pembelajaran Group Investigation. Untuk $\mathrm{H}_{0 \mathrm{~B}}$ ditolak sehingga kesimpulannya terdapat perbedaan yang signifikan antara siswa yang memiliki motivasi tinggi, sedang dan rendah, dari hasil uji anava tersebut maka perlu dilakukan uji lanjut pasca anava. Uji lanjut pasca anava yang digunakan dalam penelitian ini adalah uji Scheffe'. Rangkuman hasil analisis dengan uji Scheffe' pada tingkat signifikan $\alpha=0,05$ dapat dilihat pada Tabel 6 . 
Tabel 6. Uji Pasca Anava

\begin{tabular}{|rrrrl|}
\hline & $\mathbf{H}_{\mathbf{0}}$ & $\mathbf{F}_{\text {tabel }}$ & $\mathbf{F}_{\text {tabel }}$ & \multicolumn{1}{l|}{ Keputusan Uji } \\
\hline Motivasi Siswa & $\mu .1=\mu .2$ & 6,0110 & 6,3237 & Ho diterima \\
\hline$\mu .2=\mu .3$ & 44,3327 & 6,3237 & Ho ditolak \\
\hline$\mu .1=\mu .3$ & 61,4554 & 6,3237 & Ho ditolak \\
\hline
\end{tabular}

Dari hasil analisis menunjukkan bahwa prestasi belajar siswa yang mempunyai motivasi belajar tinggi tidak berbeda secara signifikan dengan siswa yang mempunyai motivasi belajar sedang, prestasi belajar siswa yang mempunyai motivasi belajar sedang berbeda dengan siswa yang mempunyai motivasi rendah, dan prestasi belajar siswa yang mempunyai motivasi belajar tinggi berbeda dengan siswa yang mempunyai motivasi rendah. Hal ini sesuai dengan hasil penelitian Sadiana bahwa semakin tinggi motivasi belajar siswa dan kebiasaan belajar maka semakin tinggi pula prestasi belajar matematika yang dicapai siswa tersebut[13].

\section{KESIMPULAN}

1. Prestasi belajar matematika siswa dengan model Team Assisted Individualization (TAI) lebih baik dibandingkan prestasi belajar matematika siswa dengan model Group Investigation (GI).

2. Siswa dengan motivasi tinggi mempunyai prestasi belajar matematika yang relatif sama dengan siswa motivasi sedang. Sedangkan siswa dengan motivasi tinggi dan sedang mempunyai prestasi belajar matematika yang lebih baik dibandingkan siswa dengan motivasi rendah.

3. Tidak terdapat interaksi antara model pembelajaran dan motivasi terhadap prestasi belajar matematika siswa. Hal ini dimungkinkan karena tidak adanya variabel bebas lain yang juga berpengaruh diantaranya kreativitas siswa, minat siswa, IQ, gaya belajar siswa dan lain-lain.

\section{DAFTAR PUSTAKA}

[1] H. Budiman, M. R. Rasyid, R. Idris, "Perbedaan Tingkat Pemahaman Matematika Peserta Didik Kelas VIII Yang Diajar Menggunakan Kurikulum Tingkat Satuan Pendidikan (KTSP) dan Kurikulum 2013 di SMPN 1 dan SMPN 2 Marbo Kab. Takalar", Jurnal Matematika dan Pembelajaran (MaPaN)”, Vol. 5, No. 1, pp. 125-141, 2017.

[2] N. R. Siregar, "Persepsi Siswa pada Pelajaran Matematika: Studi pendahuluan pada siswa yang menyenangi game", Prosiding Temu Ilmiah X Ikatan Psikologi Perkembangan Indonesia, pp. 224-232, 2017.

[3] M. Kalantzis, "Elements of a Science of Education", The Australian Educational Researcher,Vol. 33, No. 2, August 2016.

[4] P. B. Darmono, "Eksperimentasi Model Team Assisted Individualization (TAI) dan Student Team Achievement Division (STAD) Pada Materi Logaritma Ditinjau Dari Motivasi Belajar Siswa Kelas X SMA Negeri SeKabupaten Purworejo Tahun Pelajaran 2011 / 2012”, Vol. 4, No. 10, pp. 875-884, 2016.

[5] I. Kurniasih dan B. Sani, "Ragam Pengembangan Model Pembelajaran”, Jakarta: Kata Pena, 2015.

[6] Sardiman A.M., "Interaksi dan Motivasi Belajar Mengajar", Jakarta: Rajawali, 2014.

[7] M. S. Abdurrahman and I. M. Garba, "The Impact of Motivation on Students", Academic Achievement In Kebbi State Junior Secondary School Mathematics, Vol. 2, No. 12, Pp. 1-15, 2014.

[8] Sugiyono, "Metode Penelitian Kuantitatif, Kualitatif, dan R\&D", Bandung: ALFABETA, 2015.

[9] Budiyono, "Statistika Untuk Penelitian", Surakarta: UNS Press, 2013.

[10] E. Hariyati, M. Mariyana, B. Usodo, "Efektivitas Model Pembelajaran Kooperatif Tipe Team Assisted Individualization (TAI) dan Problem Based Learning (PBL) Pada Prestasi Belajar Matematika Ditinjau dari Multiple Intelligences Siswa SMP Kabupaten Lampung Timur Tahun Pelajaran 2012/2013”, Jurnal Pembelajaran Matematika, Vol. 1, No. 7, pp. 721-731, 2013.

[11] R. D. Laksono, "Pembelajaran Kimia Dengan Model Kooperatif Team Assisted Individualization Menggunakan Media Moodle Ditinjau dari Kreativitas Siswa”, Media Prestasi Jurnal Ilmiah STKIP PGRI Ngawi, Vol. 12 No. 2, pp. 27-32, 2013.

[12] L. T. Medyasari, "Efektivitas Model Pembelajaran Group Investigation Berbantuan Kartu Soal", Jurnal Aksioma, Vol. 8, No. 1, pp. 65-75, 2017.

[13] S. Lase, "Hubungan Antara Motivasi dan Kebiasaan Belajar Terhadap Prestasi Belajar Matematika Siswa SMP", Jurnal Warta, Edisi 56, April 2018. 